Article

\title{
Removal of Salicylic and Ibuprofen by Hexadecyltrimethylammonium-Modified Montmorillonite and Zeolite
}

\author{
Jiyeon Choi ${ }^{(D)}$ and Won Sik Shin * $\mathbb{1}$ \\ School of Architecture, Civil, Environmental and Energy Engineering, Kyungpook National University, \\ Daegu 41566, Korea; iamchoig@gmail.com \\ * Correspondence: wshin@knu.ac.kr; Tel.: +82-53-950-7584
}

Received: 9 September 2020; Accepted: 7 October 2020; Published: 10 October 2020

check for updates

\begin{abstract}
The removal of salicylic acid (SA) and ibuprofen (IB) by sorption onto HDTMA-modified montmorillonite (HM) and zeolite (HZ) was investigated at $\mathrm{pH}$ 7. The single sorption data were fitted well by the Freundlich, Langmuir, Dubinin-Radushkevich (DR), and Polanyi-Dubinin-Manes (PDM) models $\left(R^{2}>0.94\right)$. The sorption affinity of Freundlich and the maximum sorption capacity of Langmuir and PDM models of pharmaceuticals onto HM were consistently higher than that of $\mathrm{HZ}$ mainly owing to the higher organic carbon content. In addition, the $K_{\mathrm{F}}, q_{\mathrm{mL}}$, and $q_{\mathrm{m}}$ values were in the order of IB $>$ SA owing to higher hydrophobicity and molar volume. Since the predominant speciation of SA and IB is anionic at $\mathrm{pH} 7(>\mathrm{pKa})$, sorption onto HM occurs mainly by the two-dimensional surface adsorption onto the pseudo-organic medium in the HM, whereas the interaction of anionic pharmaceuticals with the positively charged "head" of HDTMA is responsible for HZ. Sorption isotherms were fitted well by the PDM model, which indicated that pore-filling was one of the dominating sorption mechanisms. The extended Langmuir model, modified Langmuir competitive model, and ideal adsorbed solution theory employed with Freundlich and Langmuir sorption models were applied to predict binary sorption. The effect of competition between the solutes was clearly evident in the characteristic curves; the maximum sorbed volume $\left(q_{\mathrm{v} . \mathrm{m}}\right)$ was reduced, and the sorbed volume $\left(q_{\mathrm{v}}\right)$ had a wider distribution toward the sorption potential density.
\end{abstract}

Keywords: binary; HDTMA-montmorillonite; HDTMA-zeolite; pharmaceuticals; Polanyi theory; sorption

\section{Introduction}

The nonsteroidal anti-inflammatory drugs (NSAIDs) constitute a class of active pharmaceutical ingredients (APIs) and have been widely used medications across the world [1]. NSAIDs can be classified as anti-inflammatory, analgesic, and antipyretic [2]. Aspirin (known as acetylsalicylic acid, ASA) and ibuprofen (IB) are commonly used in clinical medicine as pain relieving, analgesic, and anti-inflammatory drugs [3-5]. Aspirin is a widely sold "over the counter" drug and metabolized to salicylic acid (SA) [5]. A few NSAIDs including ibuprofen, naproxen, propyphenazone, and salicylic acid have been detected up to ppb levels in surface water over the countries [6]. SA, a phytohormone, has been also used in the growth and development of the whole plant [7]. Recently, most of the pharmaceuticals have no regulatory standards yet, but have received attention due to the potential negative effects of these compounds on ecosystems and public health. SA and IB are frequently found in significant quantities in the effluents from wastewater treatment plants in Europe and North America [2]. ASA and IB are frequently detected in Korean rivers [8].

Pharmaceutical pollutants in aquatic systems have been treated by physical, biochemical, and chemical processes. Although technologies based on membranes, reverse osmosis, ozonation, 
and oxidation are highly efficient, the operational costs are high. To remove pharmaceuticals from aquatic environment, sorption is one of the main physical processes [9]. Sorbent materials (e.g., activated carbon $[10,11]$, clay [12], and organoclay [12,13]) have been typically used to remove pharmaceuticals via sorption. An alternative is to use surfactant-modified clay minerals, namely organoclays. Natural clays (e.g., montmorillonite and bentonite) are inherently hydrophilic owing to the hydration of inorganic cations that exist in the interlayers of clay. The permanent negative charges in the natural clays can be modified by cationic surfactants. This surfactant-modified clay mineral enhances the removal of organic pollutants. Organoclays are prepared by simply exchanging inorganic cations on the clay surface by organic cations with long hydrocarbon chains such as the hexadecyltrimethylammonium (HDTMA) cation [14]. HDTMA modification of zeolites effectively sorbed hydrophobic organic contaminants such as benzene, phenol, and toluene [15]. Recently, several studies have suggested the potential application of organoclays for removing pharmaceuticals from water; amoxicillin, sulfamethoxazole, and trimethoprim [12], diclofenac sodium [13], and $\beta$-lactam [16]. Once the HDTMA cation is bound to the montmorillonite and zeolite, HDTMA is not leaching and thus not harmful for wildlife. Clay-bound HDTMA is significantly less toxic to bacteria than free HDTMA [17]. Li et al. [18] have also shown that HDTMA, when bound to the zeolite surface, was not toxic to microorganisms. HDTMA bound to the zeolite surface did not inhibit microbial growth [19].

Typically, the traditional Freundlich and Langmuir isotherm models have been used to predict pharmaceutical sorption on organoclays. Recently a few studies have reported on the use of the Dubinin-Radushkevich (DR) model to explain sorption mechanisms (physical versus chemical sorption) for ionizable organic compounds such as 4-chlorophenol [20] and herbicides [21] on tetrabutylammonium (DEDMAM)-montmorillonite. Fuller et al. [22] have applied the DR model for the sorption of nonionic organic solutes (benzene, $\mathrm{CCl}_{4}, \mathrm{TCE}$, and 1,2-DCB) on tetraalkylammonium bentonites. The Polanyi theory has been developed to explain sorption of contaminants by volume filling in micropores [23]. The "characteristic curve" of the Polanyi theory can describe the mechanistic sorption mechanisms. However, the applicability of Polanyi theory to evaluate pharmaceutical sorption onto organoclays has not been fully investigated yet. So far, a few studies have reported on the sorption of a single pharmaceutical onto organoclays $[12,13,16]$. However, only a few studies have investigated binary sorption of pharmaceuticals [24,25]. Anggraini et al. [24] analyzed the binary sorption of amoxicillin and ampicillin onto myristyltrimethylammonium (MTA)-montmorillonite sorption by a modified extended-Langmuir isotherm model. Ghemit et al. [25] also reported single and binary sorption mechanism of diclofenac and ibuprofen onto HDTMA-bentonite by Langmuir and Freundlich models.

In this work, the single and binary sorption behaviors of SA and IB on HM and HZ were investigated at $\mathrm{pH}$ 7. The single sorption data were predicted by Freundlich, Langmuir, DR, and Polanyi-Dubinin-Manes (PDM) models. The physicochemical properties of HM and HZ were correlated with the single-sorption model parameters to investigate the sorption mechanisms. The binary sorption of SA and IB was predicted by an extended Langmuir model (ELM), modified Langmuir competitive model (MLCM), and ideal adsorbed solution theory (IAST).

\section{Materials and Methods}

\subsection{Materials}

The physicochemical properties of salicylic acid and ibuprofen are summarized in Table 1. ${ }^{14} \mathrm{C}$-radiolabeled salicylic acid (SA) with a specific activity of $0.1 \mathrm{mCi} / \mathrm{mL}$ and ibuprofen (IB) with a specific activity of $0.1 \mathrm{mCi} / \mathrm{mL}$ were obtained from ARC chemicals (Saint Louis, MO, USA) and used as radiotracers. To prepare stock solutions of unlabeled pharmaceuticals, SA ( $\geq 99 \%$, Sigma-Aldrich, Munich, Germany) dissolved in HPLC-grade methanol (99.9\%, Merck, Munich, Germany) and IB ( $\geq 98 \%$, Fluka, Buchs, Switzerland) dissolved in ultrapure water (Nex Power 1000, Human Corporation, Seoul, Korea) with high concentrations. Electrolyte solution used in experiments was prepared in 
distilled and deionized water (DDI, MilliporeSigma ${ }^{\mathrm{TM}}$ Synergy $^{\mathrm{TM}}$, Thermo Fisher Scientific, Waltham, MA, USA) containing $10 \mathrm{mM}$ of $\mathrm{KNO}_{3}\left(99 \%\right.$, Daejung Chemical Co., Siheung, Korea) with $1 \%$ of $\mathrm{NaN}_{3}$ (99\%, Duksan Chemical Co., Ansan, Korea) as a bacterial inhibitor. The solution $\mathrm{pH}$ was adjusted to 7 using a 10-mM phosphate buffer (4.3 $\mathrm{mM} \mathrm{NaH}_{2} \mathrm{PO}_{4}$ (98.0-102.0\%, Duksan, Ansan, Korea) + $5.7 \mathrm{mM}$ $\mathrm{Na}_{2} \mathrm{HPO}_{4}$ (min. 98.0\%, Duksan, Ansan, Korea), respectively.

\subsection{Sorbents Preparation and Characterization}

To prepare HM and HZ, the impurities in the montmorillonite-KSF (Aldrich Chemical Co., Munich, Germany) and zeolite (Wangpyo Chemical Co., Pohang, Korea) were removed by washing them several times with DDI water at $60{ }^{\circ} \mathrm{C}$ [26]. A cationic surfactant, hexadecyltrimethylammonium chloride (HDTMA chloride solution, $25 \mathrm{wt} \%$, Aldrich Chemical Co., Munich, Germany), was used as an organic modifier. HM and HZ were prepared by the cation-exchange adsorption of HDTMA onto the washed montmorillonite and zeolite to the extent of $100 \%$ cation-exchange capacity (CEC) [26]. For preparing HM and HZ, $31 \mathrm{~g}$ of washed montmorillonite and zeolite was added into $1 \mathrm{~L}$ of a $5000 \mathrm{mg} / \mathrm{L}$ (for HM) and $1400 \mathrm{mg} / \mathrm{L}$ (for HZ) HDTMA solution in a 2-L glass beaker. The suspension was thoroughly mixed with a mechanical stirrer for $24 \mathrm{~h}$ at $250 \mathrm{rpm}$. Then, $\mathrm{HM}$ and $\mathrm{HZ}$ were washed again with ultrapure water to remove remaining free surfactant. The collected $\mathrm{HM}$ and HZ were dried in an oven for $1 \mathrm{~d}$ at $60^{\circ} \mathrm{C}$, sieved through a US standard No. 200 sieve $(75 \mu \mathrm{m})$ and kept in an amber bottle until use.

Table 1. Physicochemical properties of salicylic acid (SA) and ibuprofen sodium (IB).

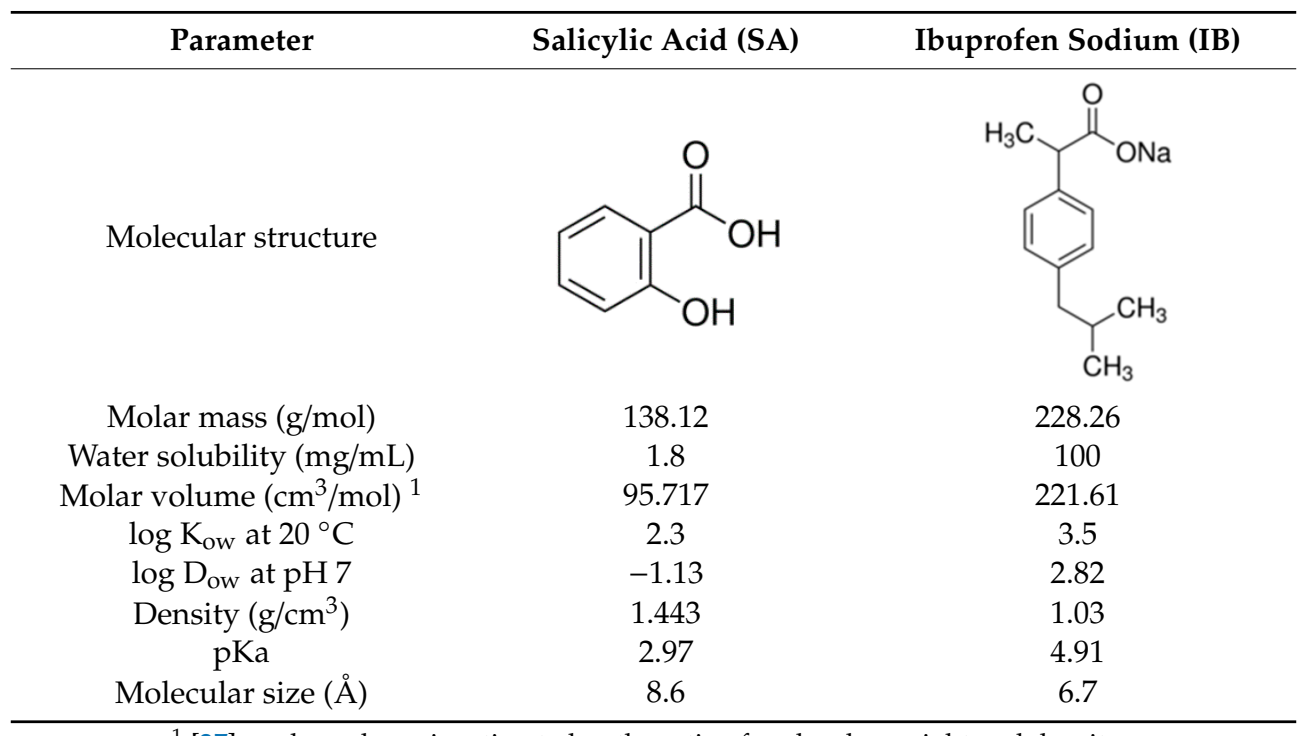

${ }^{1}$ [27]: molar volume is estimated as the ratio of molecular weight and density.

Organic carbon content $\left(f_{\text {oc }}\right)$ in the $\mathrm{HM}$ and $\mathrm{HZ}$ was determined by an elemental analyzer (Flash 2000, Thermo Fisher, Waltham, MA, USA). Specific surface area $\left(A_{\mathrm{BET}}\right)$ was calculated by $\mathrm{N}_{2}$ adsorption/desorption data fitted to the Brunauer-Emmett-Teller (BET) model (Autosorb-iQ and Quadrasorb Si, Quantachrome, Boynton Beach, FL, USA). The sodium acetate method (US EPA method 9081) was used to measure the CEC [28]. The $\mathrm{pH}$ of point of zero charge $\left(\mathrm{pH}_{\mathrm{PZC}}\right)$ of the sorbents was determined by the method by Appel et al. [29]. The X-ray diffraction (XRD, X'pert PRO MRD, Malvern PANalytical, Malvern, Almelo, The Netherlands) with a $\mathrm{Cu} \mathrm{K} \alpha$ source (40 kW, $25 \mathrm{~mA}$ ) in range of $1-25^{\circ}$, a time per step of $1 \mathrm{~s}$ and analyzed by the Bragg equation $(\mathrm{n} \lambda=2 \mathrm{~d} \sin \theta)$ was used to determine $\mathrm{d}$-spacing. 


\subsection{Sorption Isotherm of Pharmaceuticals onto HM and HZ}

A subsample of the stock solution was diluted with an electrolyte solution to prepare a solution for sorption. The radiolabeled SA and IB were injected into an aqueous solution containing unlabeled pharmaceuticals to yield $2000 \mathrm{cpm} / \mathrm{mL}$. Single-sorption experiments were conducted using 40-mL amber vials with Teflon-faced silicon septa (Kimble Chase, Vineland, NJ, USA) at $25{ }^{\circ} \mathrm{C}$. At first, $0.5 \mathrm{~g}$ of $\mathrm{HM}$ or $\mathrm{HZ}$ was added into the vial and then filled with six different initial concentrations of SA $(0.072-0.724 \mathrm{mmol} / \mathrm{L})$ and IB $(0.044-0.438 \mathrm{mmol} / \mathrm{L})$ solution without headspace. The vials were shaken at $150 \mathrm{rpm}$ for $2 \mathrm{~d}$ at $25^{\circ} \mathrm{C}$ and centrifuged for $40 \mathrm{~min}$ at $1500 \mathrm{rpm}$ to separate the aqueous solution. A total of $1 \mathrm{~mL}$ of the supernatant was mixed with $8 \mathrm{~mL}$ of an Ecolite+ liquid scintillation cocktail (MP Biochemicals, LLC., Irvine, CA, USA), and radioactivity (as a tracer of chemical concentration) in the aqueous phase was measured by a liquid scintillation counter (LSC, Tri-Carb 2900TR, Perkin-Elmer Co., Waltham, MA, USA).

For binary (SA/IB) sorption, binary solution was prepared with mixing SA and IB at an equal molar ratio. To measure each solute concentration, $\mathrm{SA} / \mathrm{IB}$ mixture solution was prepared by i) injecting radiolabeled SA $\left({ }^{14} \mathrm{C}-\mathrm{SA}\right)$ into unlabeled SA/IB and ii) injecting radiolabeled IB $\left({ }^{14} \mathrm{C}-\mathrm{IB}\right)$ into unlabeled $\mathrm{SA} / \mathrm{IB}$, respectively. After sorption, the equilibrium concentrations of the binary solutions were determined by LSC. All experiments were performed in triplicate.

The sorption isotherm models were estimated by the single sorption models (Freundlich, Langmuir, DR, and PDM model) and the bisolute sorption models (ELM, MLCM, and IAST) as listed in Table 2. The sorption model parameters were estimated by non-linear regression using a commercial software, TableCurve 2D ${ }^{\circledR}$ (Version 5.01, SYSTAT Software, Inc.). The ELM and MLCM parameters were determined using a Matlab ${ }^{\circledR}$ curve-fitting toolbox (Version R2019a, The MathWorks, Inc.).

Table 2. Sorption isotherm models.

\begin{tabular}{|c|c|c|}
\hline \multicolumn{3}{|l|}{ Model/Equation } \\
\hline Single-Solute Sorption Isotherm & Equation & Ref. \\
\hline $\begin{array}{l}\text { Freundlich } \\
q=K_{F} C^{N_{F}}\end{array}$ & (1) & - \\
\hline Langmuir & & \\
\hline$q=\frac{q_{m L} b_{L} C}{1+b_{L} C}$ & $(2)$ & - \\
\hline Dubinin-Radushkevich (DR) & & \\
\hline$q=q_{m D} \exp \left(-\beta_{D} \varepsilon^{2}\right)$ & (3) & {$[20,21]$} \\
\hline$E=\frac{1}{\sqrt{2 \beta_{D}}}$ & $(4)$ & \\
\hline $\begin{array}{l}\text { Polanyi-Dubinin-Manes (PDM) } \\
\qquad q=q_{\mathrm{m}} \exp \left\{-a\left(\frac{\varepsilon_{s w}}{V_{m}}\right)^{b}\right\}\end{array}$ & $(5)$ & {$[23,30-32]$} \\
\hline Bi-Solute Sorption Isotherm & Equation & Ref. \\
\hline Extended Langmuir model (ELM) & & \\
\hline$q_{i}=\frac{q_{m L, i} b_{L, i} C_{i}}{1+\sum_{j=1}^{2} b_{L, j} C_{j}}$ & $(6)$ & [33] \\
\hline Modified Langmuir competitive model (MLCM) & & \\
\hline$q_{i}=\frac{q_{m L, i} b_{i}\left(C_{i} / \eta_{i}\right)}{1+\sum_{i=1}^{2} b_{j}\left(C_{i} / \eta_{i}\right)}$ & $(7)$ & {$[34,35]$} \\
\hline$\pi=\frac{R T}{A} \int_{0}^{C_{1}^{*}} \frac{q_{1}}{C_{1}} d C_{1}=\frac{R T}{A} \int_{0}^{C_{2}^{*}} \frac{q_{2}}{C_{2}} d C_{2}=\cdots=\frac{R T}{A} \int_{0}^{C_{N}^{*}} \frac{q_{N}}{C_{N}} d C_{N}$ & (8) & [36-39] \\
\hline
\end{tabular}




\section{Results and Discussion}

\subsection{Characterization of the Sorbents}

The physicochemical properties of the sorbents, such as the $f_{\mathrm{oc}}$, pore size, $A_{\mathrm{BET}}, \mathrm{CEC}$, and $\mathrm{pH} \mathrm{PZC}_{\text {, }}$ are given in Table 3. Both $f_{\mathrm{oc}}$ and $A_{\mathrm{BET}}$ of $\mathrm{HM}\left(f_{\mathrm{oc}}=7.71 \% ; A_{\mathrm{BET}}=25.39 \mathrm{~m}^{2} / \mathrm{g}\right)$ were higher than those of $\mathrm{HZ}\left(f_{\mathrm{oc}}=2.03 \% ; A_{\mathrm{BET}}=24.17 \mathrm{~m}^{2} / \mathrm{g}\right)$, whereas the pore size of $\mathrm{HZ}(124.2 \AA)$ was higher than that of $\mathrm{HM}(97.31 \AA)$. The $A_{\mathrm{BET}}$ and pore size of $\mathrm{HM}$ and $\mathrm{HZ}$ affects the sorption properties [40]. The CEC of HZ (61.5 meq/100 g) was three times higher than that of HM (23.3 meq/100 g). The $\mathrm{pH}_{\mathrm{PZC}}$ indicates that net charge of $\mathrm{HM}$ and $\mathrm{HZ}$ was negative when $\mathrm{pH}$ was higher than $\mathrm{pH}_{\mathrm{PZC}}$. The $\mathrm{pH} \mathrm{PZC}_{\mathrm{P}}$ of $\mathrm{HM}$ and $\mathrm{HZ}$ was 1.9 and 6.2, respectively. At $\mathrm{pH} 7$, anionic speciation was the dominant form for both IB (anionic speciation $=98.4 \%$, pKa $=4.91$ ) and SA (anionic speciation $=99.9 \%, \mathrm{pKa}=2.97$ ) because the working solution $\mathrm{pH} 7$ was greater than $\mathrm{pKa}$, as shown in Figure S1. The working $\mathrm{pH}(7.0)$ of the aqueous solution was also higher than the $\mathrm{pH}_{\mathrm{PZC}}$ of $\mathrm{HM}$ and $\mathrm{HZ}$; thus, $\mathrm{HM}$ and $\mathrm{HZ}$ were negatively charged. Therefore the electrostatic attraction between the predominant SA and IB anions and the negatively charged HM and SA were less likely to occur.

Table 3. Physicochemical properties of the sorbents used.

\begin{tabular}{ccc}
\hline Parameter & HM & HZ \\
\hline Organic carbon content $\left(f_{\mathrm{oc}}, \%\right)$ & 7.71 & 2.03 \\
CEC $($ meq $/ 100 \mathrm{~g})$ & 23.33 & 61.5 \\
BET surface area $\left(\mathrm{A}_{\mathrm{BET}}, \mathrm{m}^{2} / \mathrm{g}\right)$ & 25.39 & 24.17 \\
Pore size $(\AA)$ & 97.31 & 124.2 \\
Pore volume $\left(\mathrm{cm}^{3} / \mathrm{g}\right)$ & 0.095 & 0.103 \\
$\mathrm{pH}$ & 3.6 & 4.9 \\
$\mathrm{PZC}$ & $<1.9$ & 6.2 \\
\hline
\end{tabular}

The XRD patterns of the washed montmorillonite and zeolite and HM and HZ are shown in Figure S2. The patterns of montmorillonite and $\mathrm{HM}$ at $2 \theta<10^{\circ}$ was different indicating changes in interlayer size caused by the surfactant modification. The diffraction peak at $5.94^{\circ}$ for the raw montmorillonite shifted to a lower angle at $4.9^{\circ}$ after modification and the interlayer spacing of HM (18.0 $\AA$ ) increased more than that of raw montmorillonite (14.8 $\AA$ ). As the surfactant was inserted into the interlayer space, the interlayer spacing was expanded owing to surfactant modification [41]. HDTMA molecules appeared to combine to form an aggregate (or a pseudo-organic phase medium) in the lamellar spacing, which reduced the BET surface area $\left(A_{\mathrm{BET}}\right)$ [42]. Zeolite is a crystalline aluminosilicate with different cavity structures. The structure of $\mathrm{HZ}$ did not exhibit changes compared to that of zeolite (e.g., new peaks) due to the unchanged crystalline nature that remained after the HDTMA modification [43]. After the HDTMA modification, the BET surface area, $A_{\mathrm{BET}}$, of sorbents (HM: $25.39 \mathrm{~m}^{2} / \mathrm{g}, \mathrm{HZ}: 24.17 \mathrm{~m}^{2} / \mathrm{g}$ ) decreased (montmorillonite: $125.7 \mathrm{~m}^{2} / \mathrm{g}$, zeolite: $53.69 \mathrm{~m}^{2} / \mathrm{g}$ ). The cation-exchange capacity (CEC) of washed montmorillonite and zeolite were $75.3 \mathrm{meq} / 100 \mathrm{~g}$ montmorillonite and $132.5 \mathrm{meq} / 100 \mathrm{~g}$ zeolite (Table S1). After the HDTMA modification, the CEC of HM (23.3 meq/100 g) and HZ (61.5 meq/100 g) were less than those of washed montmorillonite and zeolite owing to the cation exchange with HDTMA.

The $A_{\mathrm{BET}}, \mathrm{BJH}$ pore volume, and size analysis can explain the textural characterization of HM and $\mathrm{HZ}$ (Table 3). In Figure 1, the $\mathrm{N}_{2}$ adsorption-desorption isotherms at $293 \mathrm{~K}$ of $\mathrm{HM}$ and $\mathrm{HZ}$ belongs to the type IV isotherm defined by the International Union of Pure and Applied Chemistry (IUPAC) [44]. The isotherm exhibited a steep hysteresis loop of type $\mathrm{H} 1$ at a relatively high pressure $\left(\mathrm{P} / \mathrm{P}^{0}=0.4-1.0\right)$, indicating that $\mathrm{HM}$ and $\mathrm{HZ}$ were mesoporous. The pore size distribution was uniform in the range of 1.0-15 $\mathrm{nm}$ and the average pore size of HM and HZ were $9.7 \mathrm{~nm}$ and $12.4 \mathrm{~nm}$, respectively (Figure 1). The molecular size of SA $(=0.86 \mathrm{~nm})$ and IB $(=0.67 \mathrm{~nm})$ were less than the pore size of HM and HM, thus these molecules could be adsorbed by pore-filling. As shown in Figure S3, the DFT procedure 
revealed that the micropore size distribution in the $\mathrm{HM}$ and $\mathrm{HZ}$ had a unimodal distribution with the majority of pore size of $1-15 \mathrm{~nm}$. The determined ABET of $\mathrm{HM}\left(25.39 \mathrm{~m}^{2} / \mathrm{g}\right)$ was slightly greater than that of $\mathrm{HZ}\left(24.17 \mathrm{~m}^{2} / \mathrm{g}\right)$, whereas the pore volume of $\mathrm{HM}\left(0.095 \mathrm{~cm}^{3} / \mathrm{g}\right)$ was slightly smaller than that of HZ $\left(0.103 \mathrm{~cm}^{3} / \mathrm{g}\right.$; Table 3$)$.
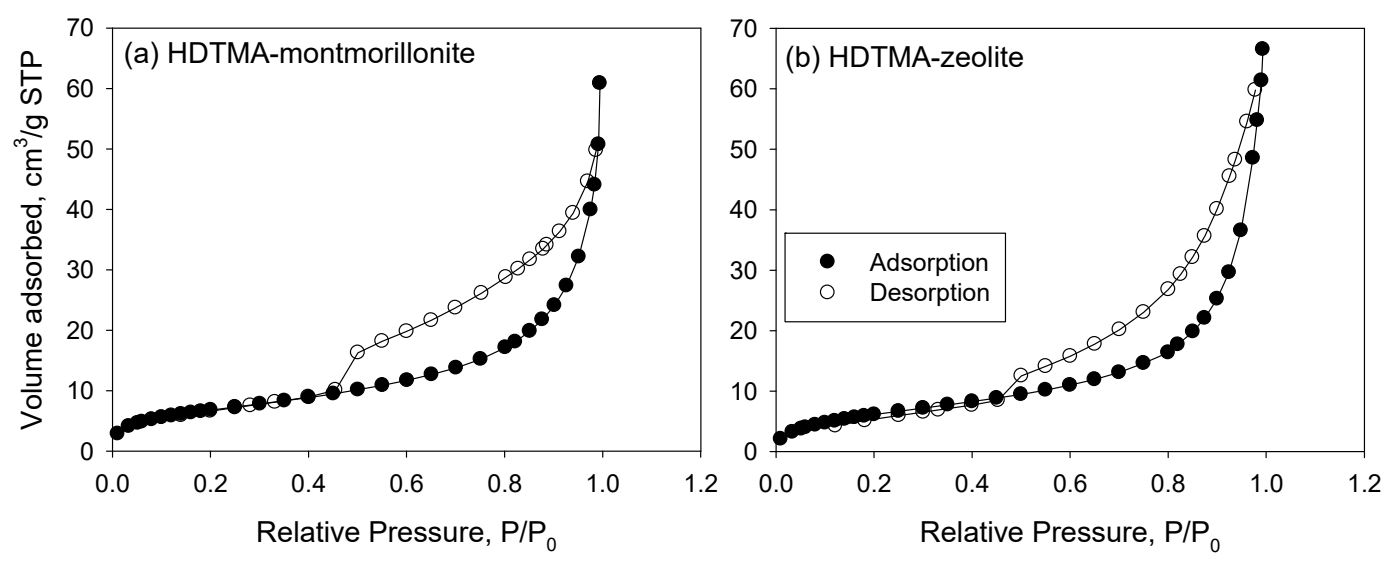

Figure 1. $\mathrm{N}_{2}$ adsorption-desorption isotherms of sorbents: (a) HDTMA-montmorillonite (HM) and (b) HDTMA-zeolite (HZ).

\subsection{Single Sorption}

The single sorption of SA and IB onto HM and $\mathrm{HZ}$ was conducted at $\mathrm{pH}$ 7. At $\mathrm{pH} 7$ (>pKa), anionic speciation was predominant ( $>99 \%$ ) for both SA and IB (Figure S2). The sorption of SA and IB onto HM and HZ is shown in Figure 2; the Freundlich, Langmuir, DR, and PDM model parameters are summarized in Table 4 . The sorption data were fitted well by all single-sorption models $\left(R^{2}>0.94\right.$; Table 4). The IB had higher $K_{\mathrm{F}}$ values than SA in both sorbents indicating the sorption affinity. The HM had consistently higher $K_{\mathrm{F}}$ than HZ mainly owing to the higher organic carbon content $\left(f_{\text {oc }}\right)$. The $N_{\mathrm{F}}$ values of the two sorbents at equilibrium were in the range of $0.49-0.77$, which showed that sorption was highly nonlinear and favorable [45]. The $q_{\mathrm{mL}} \mathrm{s}$ of HM were higher than those of $\mathrm{HZ}$ for both SA and IB, which was attributed to the higher organic carbon content $\left(f_{\mathrm{OC}}\right)$ but not to $\mathrm{CEC}, A_{\mathrm{BET}}$, and pores size. The maximum sorption capacity $\left(q_{\mathrm{mL}}\right)$ of the Langmuir model in HM (SA: $42.4 \mathrm{mmol} / \mathrm{kg}$, IB: $59.3 \mathrm{mmol} / \mathrm{kg}$ ) was higher than that of HZ (SA: $23.8 \mathrm{mmol} / \mathrm{kg}$, IB: $59.4 \mathrm{mmol} / \mathrm{kg}$ ) for both SA and IB, corresponding to increase in $f_{\text {oc }}\left(\mathrm{HM}: 7.71>\right.$ HZ: 2.03; Table 4). The $q_{\mathrm{mL}}$ of IB in HM and HZ was approximately the same. A separation factor $\left(S_{\mathrm{F}}\left[=1 /\left(1+b_{\mathrm{L}} C_{0}\right)\right]\right)$ was determined the fundamental characteristic of the Langmuir model [46]. The value of $S_{\mathrm{F}}$ describes that the isotherm types can be irreversible $\left(S_{\mathrm{F}}=0\right)$, unfavorable $\left(S_{\mathrm{F}}>1\right)$, linear $\left(S_{\mathrm{F}}=1\right)$, or favorable $\left(0<S_{\mathrm{F}}<1\right)$. All $S_{\mathrm{F}}$ values were between 0.49 and 0.78 (Table 4 and Figure S4), which indicated that the sorption of SA and IB onto sorbents was favorable [46]. 

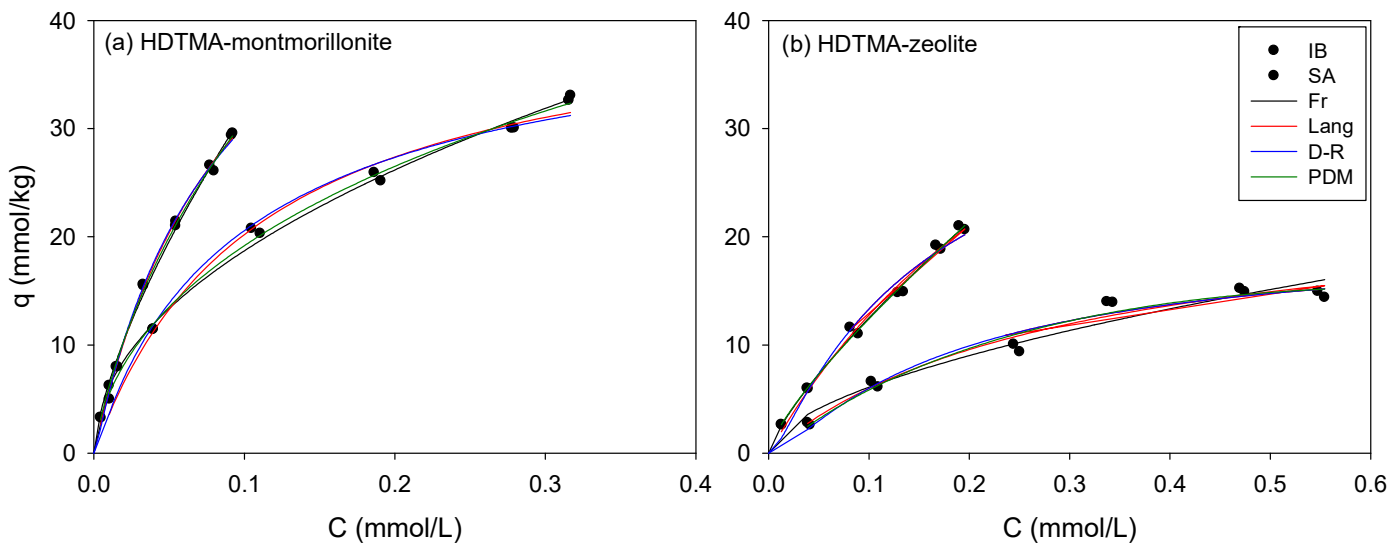

Figure 2. Single sorption of SA and ibuprofen (IB) onto (a) HM and (b) $\mathrm{HZ}$ at pH 7. Lines indicate single-sorption model fitting.

The sorption of SA and IB is attributed to interactions between the negatively charged SA and IB and the positively charged HDTMA bilayer [47]. The octanol/water partition coefficient $\left(\log K_{\text {ow }}\right)$ of IB $(=3.5)$ was higher than SA $(=2.3)$, which was consistent with an increase in the $K_{\mathrm{F}}$ of the Freundlich model and $q_{\mathrm{m}}$ of the Langmuir model. The octanol:water distribution ratio $\left(\log D_{\mathrm{ow}}\right)$ for ionizable organic compounds (IOCs) has been used to express the hydrophobicity of the organic partition coefficient in environmental studies [48]. The $\log D_{\text {ow }}$ was also in the order of IB (2.8) > SA (-1.1; Table 1). The DR model parameters are summarized in Table 4 . The $q_{\mathrm{mD}}$ values exhibited the same tendency as $K_{\mathrm{F}}$ of Freundlich and $q_{\mathrm{mL}}$ of Langmuir models. The $q_{\mathrm{mD}}$ of IB was higher than SA in both sorbents; HM had consistently higher $q_{\mathrm{mD}}$ than HZ for both SA and IB. The $q_{\mathrm{mD}}$ was consistently lower than $q_{\mathrm{mL}}$ of the Langmuir model for both $\mathrm{HM}$ and $\mathrm{HZ}$ owing to the difference in the sorption mechanisms. The $E$ values in the DR model can be used to predict whether the sorption mechanism occurs through ion-exchange or physical sorption. In this study, the estimated mean free energy, $E$ in Equation (4) were less than $8 \mathrm{KJ} / \mathrm{mol}$ indicating that SA and IB were sorbing all sorbents mainly via physical sorption [49].

The sorption in HM occurs by the surface adsorption of SA and IB onto the two-dimensional surface of the pseudo-organic medium because the dominant speciation of SA and IB is anionic at $\mathrm{pH} 7$ $(>\mathrm{pKa})[50,51]$. HDTMA modified aluminosilicate minerals (i.e., zeolite) can significantly enhance the sorption of IOCs, such as SA and IB used in this study, from aqueous solutions [42]. The hydrophobic benzene ring(s) in the SA and IB can be oriented to the inside of the HDTMA bilayers and stabilized by the hydrophobic interaction between the benzene ring(s) and the C16 tails of HDTMA cations [52]. For HZ, the interaction between anionic pharmaceuticals and HDTMA with a positively charged "head" on both inner and outer layers is a part of the sorption mechanism [47,52-54]. Dong et al. [52] reported that sorption of anionic speciation of bisphenol A onto $\mathrm{HZ}$ occurs by interaction with the positively charged HDTMA. Xie et al. [53] also explained that anion species of bisphenol A, p-chlorophenol, and phenol sorption onto HZ is attributed to Coulombic interaction. Sun et al. [47] and Krajišnik et al. [55] showed the net attractive interactions between anionic diclofenac and the positively charged HDTMA bilayer at the HZ surface. 
Table 4. Model parameters for single sorption of Pharmaceuticals onto HM and HZ at pH 7.

\begin{tabular}{|c|c|c|c|c|c|c|c|}
\hline \multirow{5}{*}{ Freundlich } & Sorbent & Solute & $\begin{array}{c}K_{F} \\
\left((\mathrm{mmol} / \mathrm{kg}) /(\mathrm{mmol} / \mathrm{L})^{N_{F}}\right)\end{array}$ & $N_{F}(-)$ & $R^{2}$ & SSE & \\
\hline & \multirow{2}{*}{$\mathrm{HM}$} & SA & $57.148 \pm 1.5973$ & $0.4850 \pm 0.0168$ & 0.9942 & 6.6340 & \\
\hline & & IB & $153.10 \pm 9.0869$ & $0.6868 \pm 0.0216$ & 0.9956 & 4.6873 & \\
\hline & \multirow{2}{*}{$\mathrm{HZ}$} & SA & $22.371 \pm 1.4158$ & $0.5643 \pm 0.0580$ & 0.9484 & 13.311 & \\
\hline & & IB & $73.983 \pm 3.9861$ & $0.7719 \pm 0.0276$ & 0.9946 & 2.7769 & \\
\hline \multirow{5}{*}{ Langmuir } & Sorbent & Solute & $q_{m L}(\mathrm{mmol} / \mathrm{kg})$ & $b(\mathrm{~L} / \mathrm{mmol})$ & $R^{2}$ & SSE & $S_{F}$ \\
\hline & \multirow{2}{*}{$\mathrm{HM}$} & SA & $42.400 \pm 2.1476$ & $9.1078 \pm 1.2636$ & 0.9844 & 17.780 & 0.5233 \\
\hline & & IB & $59.319 \pm 2.8827$ & $10.465 \pm 0.8633$ & 0.9976 & 2.5771 & 0.4887 \\
\hline & \multirow{2}{*}{$\mathrm{HZ}$} & SA & $23.773 \pm 2.3076$ & $3.3703 \pm 0.7250$ & 0.9679 & 8.2896 & 0.7479 \\
\hline & & IB & $59.373 \pm 9.2778$ & $2.7424 \pm 0.6062$ & 0.9916 & 4.3682 & 0.7848 \\
\hline \multirow{5}{*}{ DR } & Sorbent & Solute & $q_{m D}(\mathrm{mmol} / \mathrm{kg})$ & $\beta_{D}\left(\mathrm{~mol}^{2} / \mathrm{J}^{2}\right)$ & $R^{2}$ & SSE & $E(\mathrm{KJ} / \mathrm{mol})$ \\
\hline & \multirow[b]{2}{*}{$\mathrm{MM}$} & SA & $39.185 \pm 1.2220$ & $1.8253 \mathrm{E}-08 \pm 1.2547 \mathrm{E}-09$ & 0.9829 & 19.520 & 5.234 \\
\hline & & IB & $56.520 \pm 1.6017$ & $1.7807 \mathrm{E}-08 \pm 5.5576 \mathrm{E}-09$ & 0.9964 & 3.8266 & 5.299 \\
\hline & \multirow{2}{*}{$\mathrm{HZ}$} & SA & $18.750 \pm 0.7977$ & $3.2292 \mathrm{E}-08 \pm 3.1121 \mathrm{E}-09$ & 0.9658 & 8.8333 & 3.935 \\
\hline & & IB & $35.042 \pm 2.0262$ & $2.7385 \mathrm{E}-08 \pm 2.0399 \mathrm{E}-09$ & 0.9818 & 9.4266 & 4.273 \\
\hline \multirow{5}{*}{ PDM } & Sorbent & Solute & $q_{m}(\mathrm{mmol} / \mathrm{kg})$ & $a\left(\mathrm{~mL}^{2} / \mathrm{J}^{2}\right)$ & $R^{2}$ & SSE & \\
\hline & \multirow{2}{*}{$\mathrm{HM}$} & SA & $63.966 \pm 1.9805$ & $7.458 \mathrm{E}-5 \pm 2.544 \mathrm{E}-6$ & 0.9950 & 5.698 & \\
\hline & & IB & $412.08 \pm 28.383$ & $2.942 \mathrm{E}-4 \pm 7.077 \mathrm{E}-6$ & 0.9976 & 2.574 & \\
\hline & \multirow{2}{*}{$\mathrm{HZ}$} & SA & $31.435 \pm 2.6393$ & $1.037 \mathrm{E}-4 \pm 9.417 \mathrm{E}-6$ & 0.9634 & 9.454 & \\
\hline & & IB & $307.55 \pm 37.217$ & $3.623 \mathrm{E}-4 \pm 1.504 \mathrm{E}-5$ & 0.9932 & 3.505 & \\
\hline
\end{tabular}


The PDM model was proposed to normalize the aqueous concentration to the water solubility of the compounds from the Polanyi theory. In this study, PDM was also attempted because solubility $(S)$ and molar volume $\left(V_{\mathrm{m}}\right)$ are included as model parameters, considering that the solubility and molar volume of SA and IB are considerably different. The Polanyi theory has been used to describe the sorption process of organic compounds in highly meso- and microporous sorbents, which indicates that sorption occurs by the pore-filling mechanism [22]. In the PDM model (Equation (5)), the exponent $b=2$ corresponds to a log-normal distribution of sorption energies [32]. The PDM model fitted well to the SA and IB sorption data $\left(R^{2}>0.963\right)$, as shown in Figure 2. The PDM model parameters are summarized in Table 4 . It was observed that the maximum sorption capacity $\left(q_{\mathrm{m}}\right)$ of SA was less than IB and the $q_{\mathrm{m}}$ of HM (SA: $63.97 \mathrm{mmol} / \mathrm{kg}$, IB: $412.08 \mathrm{mmol} / \mathrm{kg}$ ) was higher than that of HZ (SA: $31.44 \mathrm{mmol} / \mathrm{kg}$, IB: $307.55 \mathrm{mmol} / \mathrm{kg}$ ).

The correlation or the "characteristic" curve, the plot of sorbed volume $\left(q_{\mathrm{v}}\right)$ against the Polanyi potential normalized by molar volume $\left(\varepsilon_{\mathrm{sw}} / V_{\mathrm{m}}\right)$, is shown in Figure 3, together with model fitting. Although the pore size of HM (97.3 $\AA$ ) was less than that of HZ (124.2 $\AA$; Table 3), the maximum sorbed volume $\left(q_{\mathrm{v}, \mathrm{m}}\right)$ of HM was higher than that of HZ for both SA and IB (Table 5). The maximum sorbed volume $\left(q_{\mathrm{v}, \mathrm{m}}\right)$ was also affected by the hydrophobicity of pharmaceuticals $\left(\log \mathrm{K}_{\mathrm{ow}}\right)$ and $f_{\mathrm{oc}}$ of $\mathrm{HM}$ and HZ organoclays. This indicates that pore-filling as well as two-dimensional surface sorption (HM) and hydrophobic attraction (HZ) are involved in the sorption process.

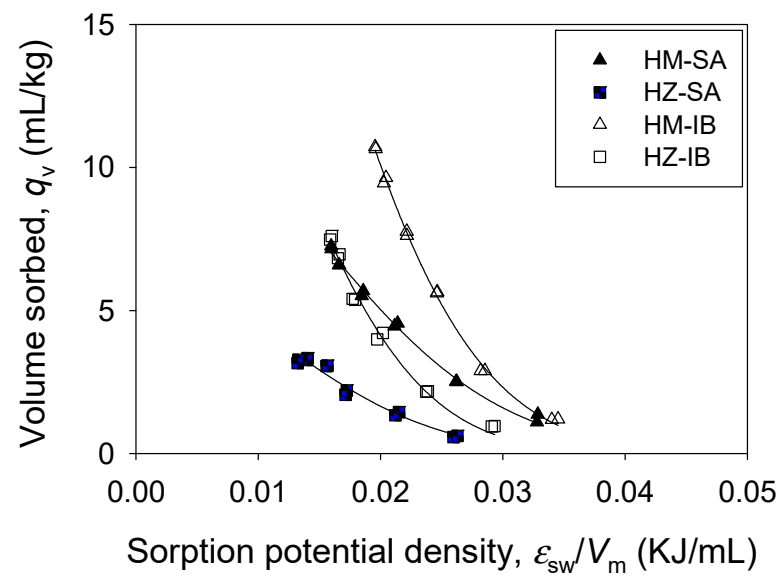

Figure 3. Characteristic curves of SA and IB sorption onto HM and HZ.

Table 5. Summary of characteristic curves of single and binary sorption of SA and IB onto HM and HZ at $\mathrm{pH} 7$.

\begin{tabular}{cccccc}
\hline Sorbent & Solute & $\boldsymbol{q}_{V, \boldsymbol{m}}(\mathbf{m L} / \mathbf{k g})$ & $\boldsymbol{\alpha}(\boldsymbol{-})$ & $\boldsymbol{R}^{\mathbf{2}}$ & SSE \\
\hline \multirow{2}{*}{$\mathrm{HM}$} & SA & $6.123 \pm 0.190$ & $74.51 \pm 2.541$ & 0.9950 & 0.0522 \\
& IB & $91.32 \pm 6.290$ & $294.0 \pm 7.070$ & 0.9976 & 0.1264 \\
\hline \multirow{2}{*}{$\mathrm{HZ}$} & SA & $3.009 \pm 0.253$ & $103.6 \pm 9.408$ & 0.9634 & 0.0866 \\
& IB & $68.16 \pm 8.248$ & $361.9 \pm 15.03$ & 0.9932 & 0.1721 \\
\hline \multirow{2}{*}{$\mathrm{HM}$} & SA in SA/IB & $3.668 \pm 0.175$ & $59.20 \pm 1.884$ & 0.9936 & 0.0143 \\
& IB in SA/IB & $69.87 \pm 4.306$ & $266.4 \pm 4.841$ & 0.9979 & 0.0367 \\
\hline \multirow{2}{*}{$\mathrm{HZ}$} & SA in SA/IB & $3.293 \pm 0.123$ & $79.50 \pm 1.793$ & 0.9966 & 0.0044 \\
& IB in SA/IB & $32.28 \pm 4.959$ & $245.4 \pm 13.42$ & 0.9780 & 0.2723 \\
\hline
\end{tabular}

This "characteristic" curve can be used to identify whether the Polanyi theory mechanistically captures the sorption mechanism of pharmaceuticals by sorbents based on two assumptions. One assumption is that there is no molecular sieving effect. As mentioned before, this is true because the pore size of HM (124.2 $\AA$ ) and HZ (97.31 $\AA$; Table 3) was greater than the molecular size of SA $(8.6 \AA)$ and IB (6.7 $\AA$; Table 1$)$. The second assumption is that the molar volume of sorbates affects 
the sorption [55]. Figure 3 clearly shows the separation of the correlation curve of two pharmaceuticals (SA and IB). Several literature reported similar results for sorbents such as carbon sorbents [31], natural soil [27], polymers [23], and organoclays [20,21]. PDM was useful to describe the individual sorption isotherm data because $V_{\mathrm{m}}$ is the constant used in the regression analysis.

The characteristic curves at different temperatures were on the same curve for HM and HZ, respectively, and in accordance with the sorbent structure [23]. Long et al. [23] also have shown that the characteristic curves of naphthalene on polymer sorbents at different temperatures fall onto a single curve. The characteristic curve of the sorption of pharmaceuticals onto HM and HZ at 293, 303, and $313 \mathrm{~K}$ is shown in Figure 4. According to the Polanyi theory, all curves were essentially a single curve and had the high coefficient of determination $\left(R^{2}\right)$ of the PDM model $\left(0.94<R^{2}<0.98\right)$. Thus, to describe pharmaceutical sorption on HM and HZ, the Polanyi theory is mechanistically useful to indicate that pore-filling is also one of the dominating sorption mechanisms. The cause of differences in sorption affinity is the steric hindrance owing to the size and shape of solute molecules.
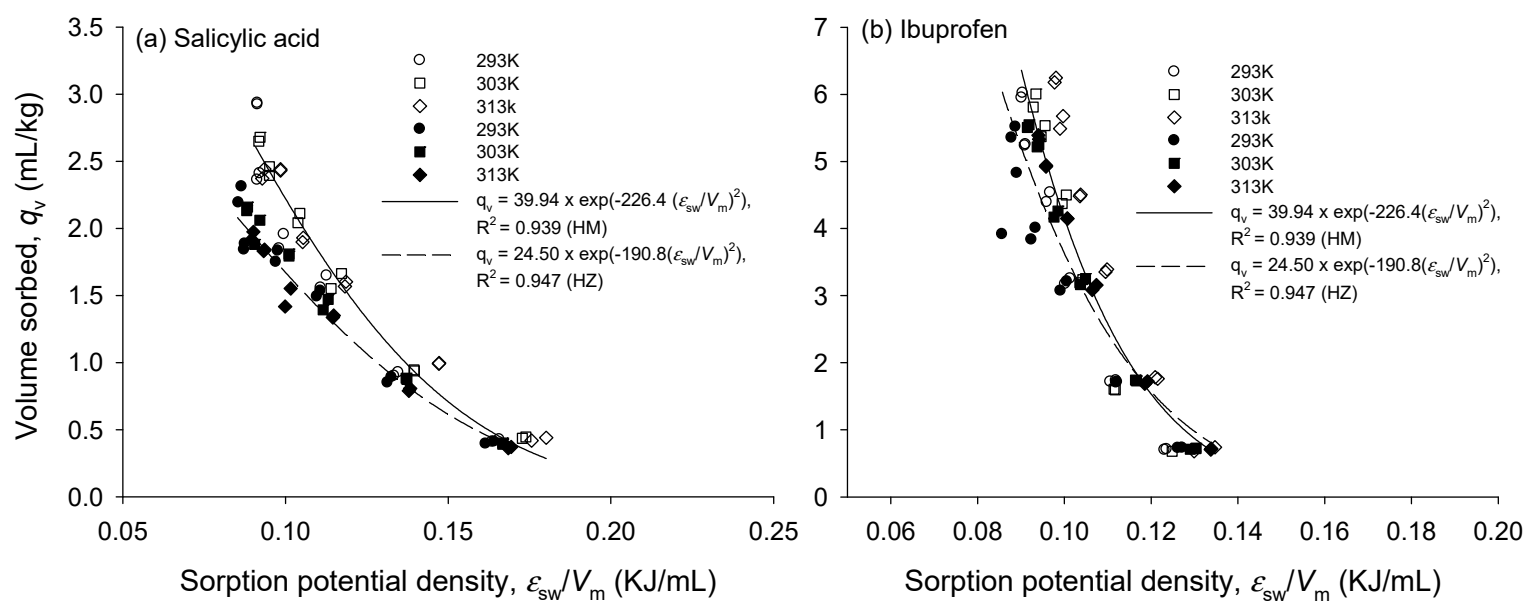

Figure 4. Effect of temperature on the characteristic curves of (a) SA and (b) IB sorption onto HM and $\mathrm{HZ}$, respectively. Empty and filled symbols represent $\mathrm{HM}$ and HZ, respectively.

In summary, the sorption mechanisms are attributed to the (i) two-dimensional surface of the pseudo-organic medium sorption for HM and the interaction between anionic pharmaceuticals and the positively charged "head" of HDTMA for HZ and the (ii) pore-filling mechanism, which can be described by the PDM model, is also possible.

\subsection{Binary Sorption}

As expected, the sorbed amount in binary sorption was less than that in single sorption. The ELM (Equation (6)), MLCM (Equation (7)), and the IAST (Equation (8))-single-sorption models (Freundlich and Langmuir) were fitted to the binary sorption data of SA/IB on HM and HZ (Figure 5). The coefficient of determination $\left(R^{2}\right)$, sum of square errors (SSE), and root mean square error (RMSE) values are listed in Table 6. The ELM $\left(0.72<R^{2}<0.95\right)$, MLCM $\left(0.93<R^{2}<0.99\right)$, and IAST $\left(0.86<R^{2}<0.99\right)$ models positively predicted the binary sorption data in SA/IB systems. The interaction coefficients, $\eta$, of MLCM explain the suppression in sorption owing to competition. In the MLCM, the higher the interaction coefficient $(\eta)$, the smaller is the inhibitory effect of pharmaceuticals on the sorption of other species [56]. The interaction coefficient $(\eta)$ of SA (1) was consistently higher than that of IB (2) for both HM ( $\eta_{1}$ : $\left.0.871, \eta_{2}: 0.532\right)$ and $\mathrm{HZ}\left(\eta_{1}: 0.341, \eta_{2}: 0.277\right)$, which explains that SA (1) was more affected than IB (2) in binary sorption (Table 6$)$. The selectivity of IB $\left(=\mathrm{K}_{\mathrm{d}, \mathrm{SA}} / \mathrm{K}_{\mathrm{d}, \mathrm{IB}}\right.$ at $\left.C_{\text {initial }}=0.05 \mathrm{mM}\right)$ was less than SA for both HM and HZ (Table S2) in the binary sorption system. 

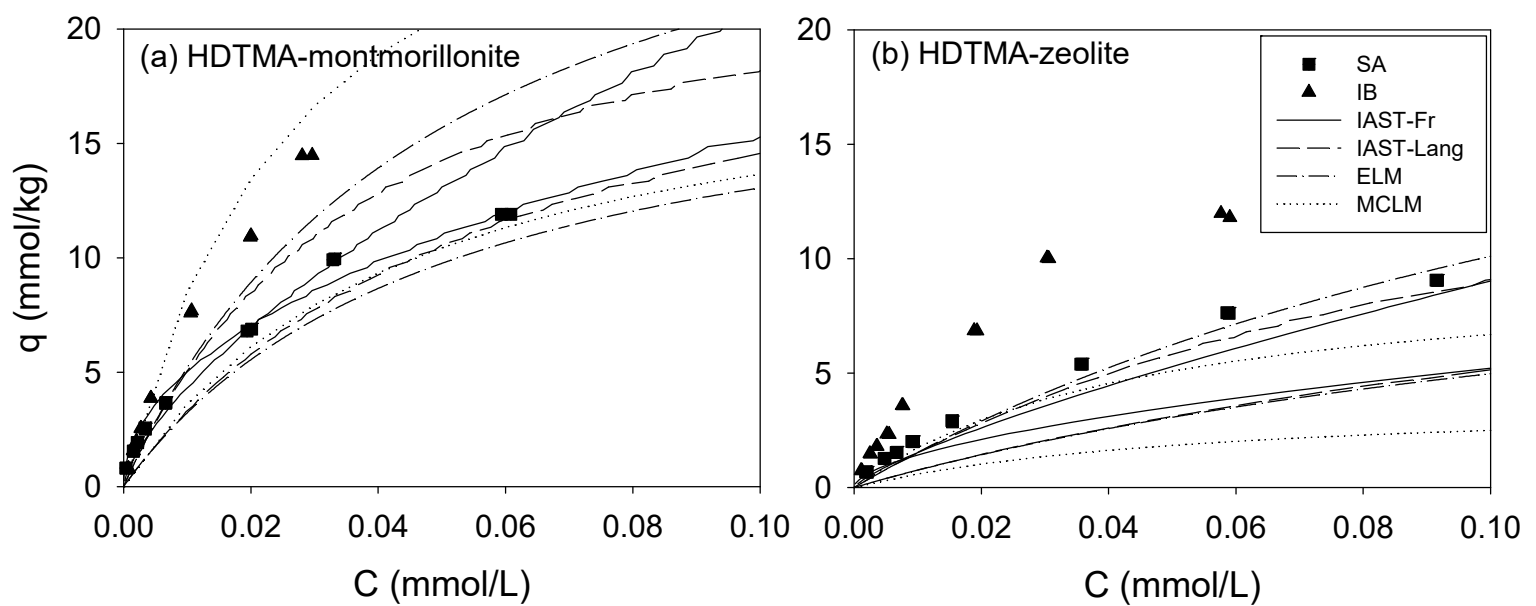

Figure 5. Binary sorption of SA/IB onto (a) $\mathrm{HM}$ and (b) $\mathrm{HZ}$ at $\mathrm{pH}$ 7. Lines indicate binary sorption model fitting.

Table 6. Model parameters for the binary sorption of $\mathrm{SA}(1)$ and $\mathrm{IB}(2)$ onto $\mathrm{HM}$ and $\mathrm{HZ}$ at $\mathrm{pH} 7$ (solutes: SA/IB).

\begin{tabular}{cccc}
\hline Model & Parameters & HM & HZ \\
\hline \multirow{3}{*}{ ELM } & $R^{2}$ & $0.8115 / 0.9468$ & $0.7180 / 0.7275$ \\
& SSE & $118.35 / 44.263$ & $104.86 / 170.40$ \\
& RMSE & $3.0172 / 1.8452$ & $2.8401 / 3.6204$ \\
\hline \multirow{2}{*}{ MLCM } & $\eta_{1}$ & $0.8711 \pm 0.1769$ & $0.3412 \pm 0.0144$ \\
& $\eta_{2}$ & $0.5317 \pm 0.0801$ & $0.2774 \pm 0.0366$ \\
& $R^{2}$ & $0.9368 / 0.9792$ & $0.9976 / 0.9821$ \\
& SSE & $15.440 / 6.670$ & $0.3362 / 4.5010$ \\
IAST-Fr & RMSE & $1.0150 / 0.6900$ & $0.1497 / 0.5478$ \\
& $R^{2}$ & $0.9942 / 0.8553$ & $0.7903 / 0.6645$ \\
& SSE & $3.6540 / 120.36$ & $77.967 / 209.80$ \\
IAST-Lang & RMSE & $0.5302 / 3.0428$ & $2.4490 / 4.0172$ \\
\hline & $R^{2}$ & $0.9676 / 0.9293$ & $0.7263 / 0.7004$ \\
& SSE & $20.355 / 58.762$ & $101.77 / 187.34$ \\
& RMSE & $1.2513 / 2.1261$ & $2.7980 / 3.7961$ \\
\hline
\end{tabular}

In addition, the Polanyi theory was analyzed for the SA/IB competition system. The correlation curve of $q_{\mathrm{v}}$ versus $\varepsilon_{\mathrm{sw}} / V_{\mathrm{m}}$ for the SA/IB competition system is shown in Figure 6. Compared to single sorption (Figure 6), a binary sorption curve (Figure 6) exhibited a wider distribution than a single-sorption curve owing to the competition for pore-filling. The $q_{\mathrm{v}, \mathrm{m}}$ of HM was higher than that of $\mathrm{HZ}$ for both SA and IB (Table 5) and the same as $q_{\mathrm{v}, \mathrm{m}}$ patterns in single sorption. In binary sorption, the $q_{\mathrm{v}, \mathrm{m}}$ of pharmaceuticals on HM (SA: $3.67 \mathrm{~mL} / \mathrm{kg}, \mathrm{IB}: 69.9 \mathrm{~mL} / \mathrm{kg}$ ) and HZ (SA: $3.29 \mathrm{~mL} / \mathrm{kg}$, IB: $32.3 \mathrm{~mL} / \mathrm{kg}$ ) were lower than those in single sorption on HM (SA: $6.12 \mathrm{~mL} / \mathrm{kg}$, IB: $91.3 \mathrm{~mL} / \mathrm{kg})$ and HZ (SA: $3.01 \mathrm{~mL} / \mathrm{kg}$, IB: $68.2 \mathrm{~mL} / \mathrm{kg}$ ), respectively. 

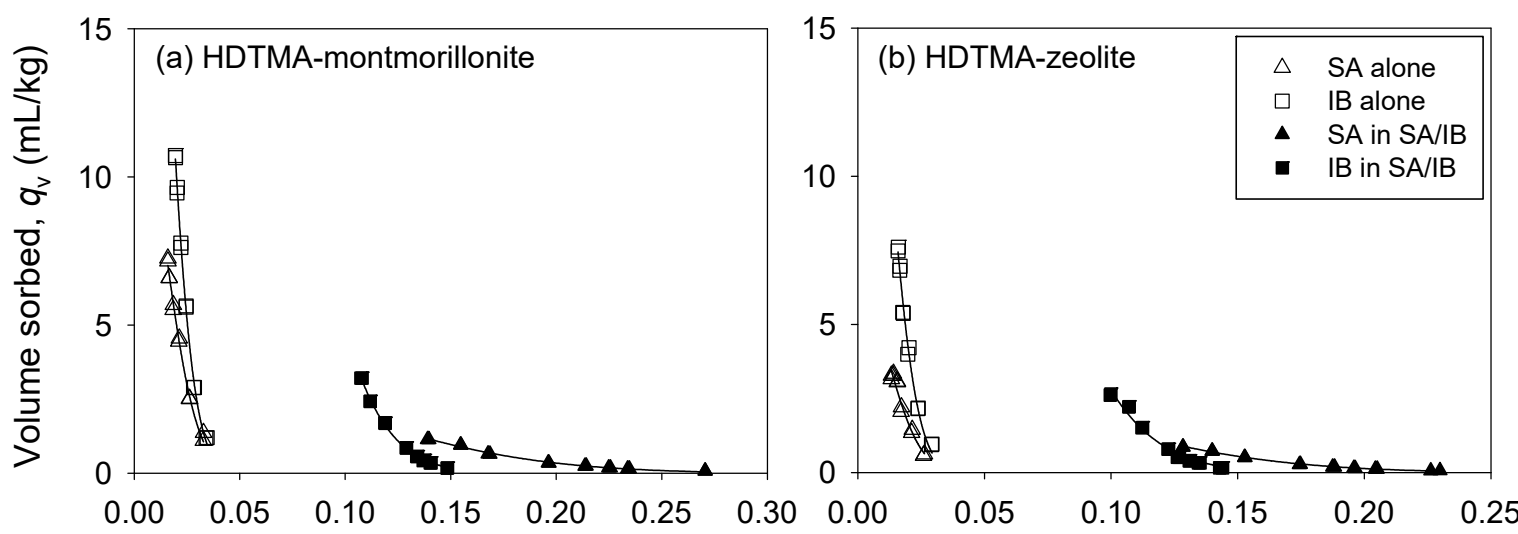

Sorption potential density, $\varepsilon_{\mathrm{sw}} / V_{\mathrm{m}}(\mathrm{KJ} / \mathrm{mL})$

Sorption potential density, $\varepsilon_{\mathrm{sw}} / V_{\mathrm{m}}(\mathrm{KJ} / \mathrm{mL})$

Figure 6. Comparison of the characteristic curves of single and binary sorption of SA/IB onto (a) HM and (b) HZ.

\section{Conclusions}

The sorption of SA and IB onto HDTMA-modified montmorillonite and zeolite was conducted at $\mathrm{pH}$ 7. This study investigated sorption behaviors of SA and IB on the HM and HZ. The single-sorption data were fitted well by the Freundlich, Langmuir, DR, and PDM models. The sorption of IB was higher than that of SA owing to its higher hydrophobicity $\left(\log K_{\mathrm{ow}}\right.$ or $\left.\log D_{\mathrm{ow}}\right)$. The Freundlich constant $\left(K_{\mathrm{F}}\right)$ and the maximum sorption capacity $\left(q_{\mathrm{mL}}\right)$ of SA and IB on HM were slightly higher than those of pharmaceuticals on $\mathrm{HZ}$, mainly owing to the higher organic carbon content $\left(f_{\mathrm{oc}}\right)$. The sorption capacity $\left(q_{\mathrm{mL}}\right)$ of SA $(42.4 \mathrm{mmol} / \mathrm{kg})$ and IB $(59.3 \mathrm{mmol} / \mathrm{kg})$ in HM was higher than that of SA $(23.8 \mathrm{mmol} / \mathrm{kg})$ and IB $(59.4 \mathrm{mmol} / \mathrm{kg})$ in $\mathrm{HZ}$, respectively. At working solution $\mathrm{pH} 7$, the anionic speciation of SA and IB are dominant. Therefore, the sorption mechanism of anionic pharmaceuticals was explained by the two-dimensional surface of the pseudo-organic medium adsorption for HM and by the interaction of anionic pharmaceuticals with the positively charged "head" of HDTMA for HZ. According to the Polanyi theory, the characteristic curves of pharmaceuticals onto HM and HZ at 293, 303, and $313 \mathrm{~K}$ fell on a single curve. The good fits of the PDM model in single solute sorption implicated that the sorption of pharmaceuticals onto HM and HZ also occurred by pore-filling. In the binary sorption, ELM, MLCM, and IAST coupled with single-sorption models fitted positively to the data $\left(0.66<R^{2}<0.99\right)$. Compared to single sorption, the $q_{\mathrm{v}, \mathrm{m}}$ of pharmaceuticals were reduced, and the characteristic curve exhibited a wide distribution owing to the competition in pore-filling. Therefore the pore-filling mechanism would be also responsible for the sorption of phenolic compounds in HM and HZ.

Supplementary Materials: The following are available online at http://www.mdpi.com/2075-163X/10/10/898/s1, Figure S1: Distribution of speciation of SA and IB as a function of $\mathrm{pH}$, Figure S2: XRD patterns of montmorillonite and HM; zeolite and HZ, Figure S3: DFT pore size distribution of organoclays, Figure S4: $S_{\mathrm{F}}$ as a function of initial concentration, Table S1: Physicochemical properties of raw clays.

Author Contributions: Conceptualization, J.C. and W.S.S.; methodology, J.C. and W.S.S.; software, W.S.S.; validation, W.S.S.; investigation, J.C.; data curation, J.C. and W.S.S.; writing-original draft preparation, J.C.; review and editing, W.S.S.; supervision, W.S.S.; project administration, W.S.S.; funding acquisition, W.S.S. All authors have read and agreed to the published version of the manuscript.

Funding: This research received no external funding.

Acknowledgments: This work was supported by Korea Environment Industry and Technology Institute (KEITI) through The Chemical Accident Prevention Technology Development Project, funded by Korea Ministry of Environment (MOE) (2019001960002).

Conflicts of Interest: The authors declare that they have no known competing financial interests or personal relationships that could have appeared to influence the work reported in this paper. 


\section{Nomenclature}

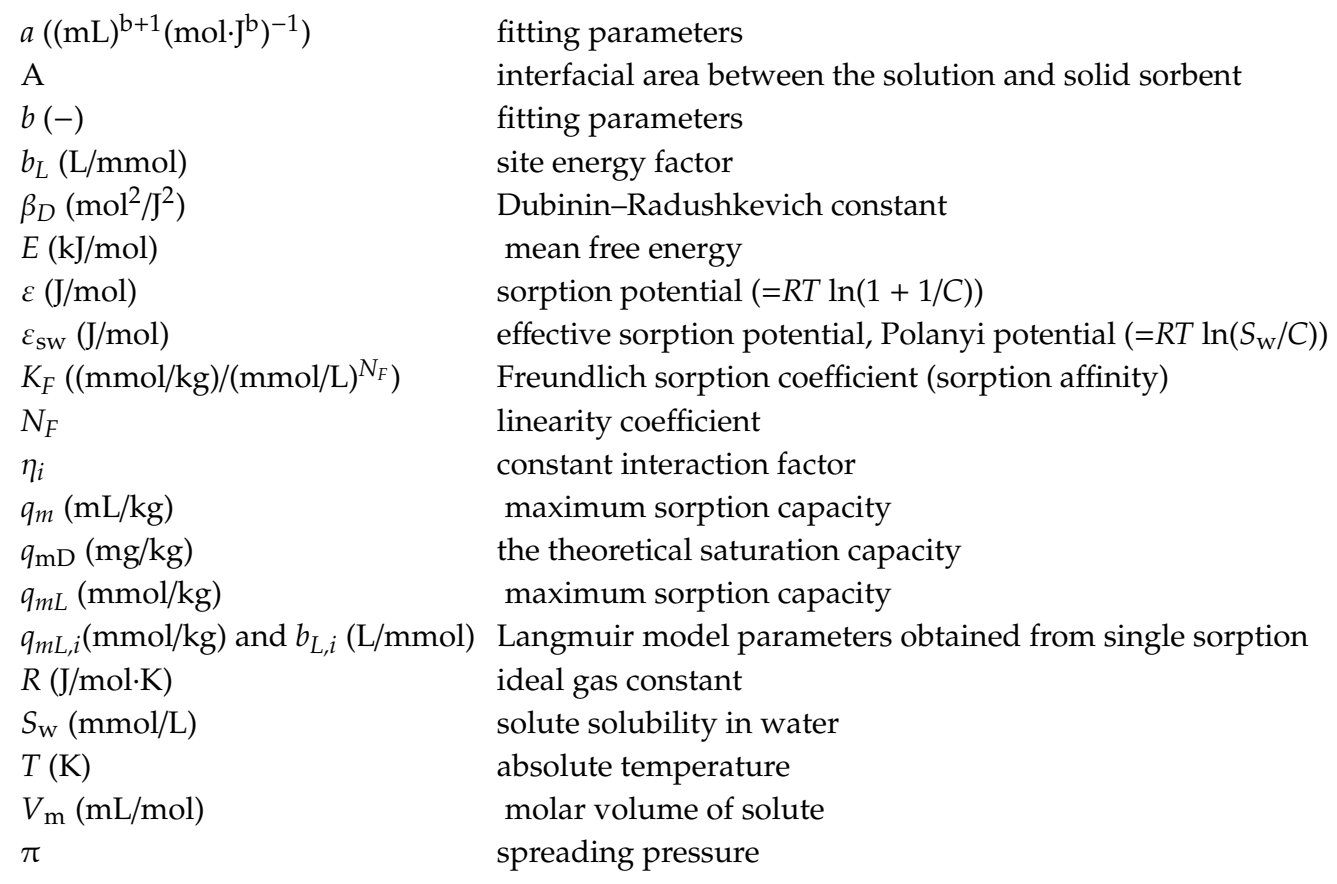

\section{References}

1. Dionísio, R.; Daniel, D.; Arenas, F.; Campos, J.C.; Costa, P.C.; Nunes, B.; Correia, A.T. Effect of pH on salicylic acid toxicity in terms of biomarkers determined in the marine gastropod Gibbula umbilicalis. Mar. Environ. Res. 2020, 158, 104995. [CrossRef] [PubMed]

2. Silva, A.; Coimbra, R.N.; Escapa, C.; Figueiredo, S.A.; Freitas, O.M.; Otero, M. Green microalgae Scenedesmus Obliquus utilization for the adsorptive removal of nonsteroidal anti-inflammatory drugs (NSAIDs) from water samples. Int. J. Environ. Res. Public Health 2020, 17, 3707. [CrossRef] [PubMed]

3. Li, Z.-M.; Wei, C.-W.; Zhang, Y.; Wang, D.-S.; Liu, Y.-N. Investigation of competitive binding of ibuprofen and salicylic acid with serum albumin by affinity capillary electrophoresis. J. Chromatogr. 2011, B879, 1934-1938. [CrossRef] [PubMed]

4. Bernal, V.; Giraldo, L.; Moreno-Piraján, J.C. Thermodynamic analysis of acetaminophen and salicylic acid adsorption onto granular activated carbon: Importance of chemical surface and effect of ionic strength. Thermochim. Acta 2020, 683, 178467. [CrossRef]

5. Essandoh, M.; Kunwat, B.; Pittman Charles, U., Jr.; Mohan, D.; Mlsna, T. Sorptive removal of salicylic acid and ibuprofen from aqueous solutions using pine wood fast pyrolysis biochar. Chem. Eng. J. 2015, 265, 219-227. [CrossRef]

6. Park, J. Pharmaceuticals in the Environment and Management Approaches in Korea; Korea Environment Institute (KEI): Seoul, Korea, 2005.

7. Raskin, I. Role of salicylic acid in plants. Annu. Rev. Plant Physiol. Plant Mol. Biol. 1992, 43, $439-463$. [CrossRef]

8. Nakdong River Water Environment Research Institute. A Survey on the Monitoring of Potentially Hazardous Compounds and Contamination Routes in Tributary of the Nakdong River System; 3rd year report; National Institute of Environmental Research (NIER): Daegu, Korea, 2015.

9. Wang, J.; Wang, S. Removal of pharmaceuticals and personal care products (PPCPs) from wastewater: A review. J. Environ. Manag. 2016, 182, 620-640. [CrossRef]

10. Mailler, R.; Gasperi, J.; Conquet, Y.; Deshayes, S.; Zedek, S.; Cren-Olivé, C.; Cartiser, N.; Eudes, V.; Bressy, A.; Caupos, E.; et al. Study of a large scale powdered activated carbon pilot: Removals of a wide range of emerging and priority micropollutants from wastewater treatment plant effluents. Water Res. 2015, 72, 315-330. [CrossRef] 
11. Rodriguez, E.; Campinas, M.; Acero, J.; Rosa, M.J. Investigating PPCP removal from wastewater by powdered activated carbon/ultrafiltration. Water Air Soil Pollut. 2016, 227, 1-4. [CrossRef]

12. Oliveira, T.D.; Fernandez, E.; Fougère, L.; Destandau, E.; Boussafir, M.; Sohmiya, M.; Sugahara, Y.; Guégan, R. Competitive association of antibiotics with a clay mineral and organoclay derivatives as a control of their lifetimes in the environment. ACS Omega 2018, 3, 15332-15342. [CrossRef]

13. Maia, G.S.; de Andrade, J.R.; da Silva, M.G.C.; Vieira, M.G.A. Adsorption of diclofenac sodium onto commercial organoclay: Kinetic, equilibrium and thermodynamic study. Powder Technol. 2019, 345, 140-150. [CrossRef]

14. Xu, S.; Boyd, S.A. Cationic surfactant adsorption by swelling and non-swelling layer silicates. Langmuir 1995, 11, 2508-2514. [CrossRef]

15. Koh, S.-M.; Dixon, J.B. Preparation and application of organo-minerals as sorbents of phenol, benzene, and toluene. Appl. Clay Sci. 2001, 18, 111-122. [CrossRef]

16. Saitoh, T.; Shibayama, T. Removal and degradation of b-lactam antibiotics in water using didodecyldimethylammonium bromide-modified montmorillonite organoclay. J. Hazard. Mater. 2016, 317, 677-685. [CrossRef]

17. Crocker, F.H.; Guerin, W.F.; Boyd, S.A. Bioavailability of naphthalene sorbed to cationic surfactant-modified smectite clay. Environ. Sci. Technol. 1995, 29, 2953-2958. [CrossRef]

18. Li, Z.; Bowman, R.S. Sorption of perchloroethylene by surfactant-modified zeolite as controlled by surfactant loading. Environ. Sci. Technol. 1998, 32, 2278-2282. [CrossRef]

19. Reeve, P.J.; Fallowfield, H.J. Natural and surfactant modified zeolites: A review of their applications for water remediation with a focus on surfactant desorption and toxicity towards microorganisms. J. Environ. Manag. 2018, 205, 253-261. [CrossRef]

20. Akçay, M. Characterization and adsorption properties of tetrabutylammonium montmorillonite (TBAM) clay: Thermodynamic and kinetic calculations. J. Colloid Interf. Sci. 2006, 296, 16-21. [CrossRef]

21. Akçay, G.; Akçay, M.; Yurdakoç, K. The characterization of prepared organomontmorillonite (DEDMAM) and sorption of phenoxyalkanoic acid herbicides from aqueous solution. J. Colloid Interf. Sci. 2006, 296, 428-433. [CrossRef]

22. Fuller, M.; Smith, J.A.; Burns, S.E. Sorption of nonionic organic solutes from water to tetraalkylammonium bentonites: Mechanistic considerations and application of the Polanyi-Manes potential theory. J. Colloid Interf. Sci. 2007, 313, 405-413. [CrossRef]

23. Long, C.; Li, A.; Wu, H.; Liu, F.; Zhang, Q. Polanyi-based models for the adsorption of naphthalene from aqueous solutions onto nonpolar polymeric adsorbents. J. Colloid Interf. Sci. 2008, 319, 12-18. [CrossRef] [PubMed]

24. Anggraini, M.; Kurniawan, A.; Ong, L.K.; Martin, M.A.; Liu, J.-C.; Soetaredjo, F.E.; Indraswati, N.; Ismadji, S. Antibiotic detoxification from synthetic and real effluents using a novel MTAB surfactant-montmorillonite (organoclay) sorbent. RSC Adv. 2014, 4, 16298. [CrossRef]

25. Ghemit, R.; Makhloufi, A.; Djebri, N.; Flilissa, A.; Zerroual, L.; Boutahala, M. Adsorptive removal of diclofenac and ibuprofen from aqueous solution by organobentonites: Study in single and binary systems, Groundw. Sustain. Dev. 2019, 8, 520-529. [CrossRef]

26. Kim, J.-H.; Shin, W.S.; Song, D.-I.; Choi, S.J. Multi-step competitive sorption and desorption of chlorophenols in surfactant modified montmorillonite. Water Air Soil Pollut. 2005, 166, 367-380. [CrossRef]

27. Xia, G.; Ball, W.P. Adsorption-partitioning uptake of nine low-polarity organic chemicals on a natural sorbent. Environ. Sci. Technol. 1999, 33, 262-269. [CrossRef]

28. United States Environmental Protection Agency (US EPA). Cation-Exchange Capacity of Soils (Sodium Acetate)-Test Methods for the Evaluation of Solid Waste: Laboratory Manual Physical Chemical Methods; US EPA: Washington, DC, USA, 2014. Available online: https:/www.epa.gov/hw-sw846/sw-846-test-method-9081cation-exchange-capacity-soils-sodium-acetate (accessed on 9 October 2020).

29. Appel, C.; Ma, L.Q.; Rhue, R.D.; Kennelley, E. Point of zero charge determination in soils and minerals via traditional methods and detection of electroacoustic mobility. Geoderma 2003, 113, 77-93. [CrossRef]

30. Allen-King, R.M.; Grathwohl, P.; Ball, W.P. New modeling paradigms for the sorption of hydrophobic organic chemicals to heterogeneous carbonaceous matter in soils, sediments, and rocks. Adv. Water Resour. 2002, 25, 985-1016. [CrossRef] 
31. Long, C.; Lu, J.D.; Li., A.; Hu, D.; Liu, F.; Zhang, Q. Adsorption of naphthalene onto the carbon adsorbent from waste ion exchange resin: Equilibrium and kinetic characteristics. J. Hazard. Mater. 2008, 150, 656-661. [CrossRef]

32. Kleineidam, S.; Schüth, C.; Grathwohl, P. Solubility-normalized combined adsorption-partitioning sorption isotherms for organic pollutants. Environ. Sci. Technol. 2002, 36, 4689-4697. [CrossRef]

33. Choy, K.K.H.; Porter, J.F.; McKay, G. Langmuir Isotherm Models Applied to the Multicomponent Sorption of Acid Dyes from Effluent onto Activated Carbon. J. Chem. Eng. Data 2000, 45, 575-584. [CrossRef]

34. Bellot, J.C.; Condoret, J.S. Modelling of liquid chromatography equilibrium. Process Biochem. 1993, 28, 365-376. [CrossRef]

35. Ghaedi, N.; Jajjati, S.; Mahmudi, Z.; Tyagi, I.; Agarwal, S.; Maity, A.; Gupta, V.K. Modeling of competitive ultrasonic assisted removal of the dyes-Methylene blue and Safranin-O using $\mathrm{Fe}_{3} \mathrm{O}_{4}$ nanoparticles. Chem. Eng. J. 2015, 268, 28-37. [CrossRef]

36. Radke, C.J.; Prausnitz, J.M. Thermodynamics of multi-solute adsorption from dilute liquid solutions. AIChE J. 1972, 18, 761-768. [CrossRef]

37. Yen, C.Y.; Singer, P.C. Competitive Adsorption of Phenols on Activated Carbon. J. Environ. Eng. 1984, 110, 976-989. [CrossRef]

38. Shin, W.S. Competitive sorption of anionic and cationic dyes onto cetylpyridinium-modified montmorillonite. J. Environ. Sci. Health Part A 2008, 43, 1459-1470. [CrossRef]

39. Song, D.-I.; Choi, J.; Shin, W.S. The modified Song isotherm model: Application to multisolute sorption of phenols in organoclays using the ideal adsorbed solution theory. Environ. Technol. 2019, 1-12. [CrossRef] [PubMed]

40. Groisman, L.; Rav-Acha, C.; Gerstl, Z.; Mingelgrin, U. Sorption of organic compounds of varying hydrophobicities from water industrial wastewater by long- and short-chain organoclays. Appl. Clay Sci. 2004, 24, 159-166. [CrossRef]

41. Zhou, Q.; Frost, R.L.; He, H.; Xi, Y. Changes in the surfaces of adsorbed para-nitrophenol on HDTMA organoclay-The XRD and TG study. J. Colloid Interf. Sci. 2007, 307, 50-55. [CrossRef]

42. Ko, C.H.; Fan, C.; Chiang, P.N.; Wang, M.K.; Lin, K.C. p-nitrophenol, phenol and aniline sorption by organo-clays. J. Hazard. Mater. 2007, 149, 275-282. [CrossRef]

43. Thanos, A.G.; Katsou, E.; Malamis, S.; Psarras, K.; Pavaltou, E.A.; Haralambous, K.J. Evaluation of modified mineral performance for chromate sorption from aqueous solutions. Chem. Eng. J. 2012, 211-212, 77-88. [CrossRef]

44. Kumar, K.V.; Gadipelli, S.; Wood, B.; Ramisetty, K.A.; Stewart, A.A.; Howard, C.A.; Brett, D.J.L.; Rodriguez-Reinoso, F. Characterization of the adsorption site energies and heterogeneous surfaces of porous materials. J. Mater. Chem. A 2019, 7, 10104. [CrossRef]

45. Bhatt, A.S.; Sakaria, P.L.; Vasudevan, M.; Pawar, R.R.; Sudheesh, N.; Bajaj, H.C.; Mody, H.M. Adsorption of an anionic dye from aqueous medium by organoclays: Equilibrium modeling, kinetic and thermodynamic exploration. RCS Adv. 2012, 2, 8663-8671. [CrossRef]

46. McKay, G.; Al Duri, B. Prediction of multicomponent adsorption equilibrium data using empirical correlations. Chem. Eng. J. 1989, 41, 9-23. [CrossRef]

47. Sun, K.; Shi, Y.; Wang, X.; Li, Z. Sorption and retention of diclofenac on zeolite in the presence of cationic surfactant. J. Hazard. Mater. 2017, 323, 584-592. [CrossRef]

48. Septian, A.; Oh, S.; Shin, W.S. Sorption of antibiotics onto montmorillonite and kaolinite: Competition modelling. Environ. Technol. 2019, 40, 2940-2953. [CrossRef]

49. El-Kamash, A.M. Evaluation of zeolite A for the sorptive removal of $\mathrm{Cs}^{+}$and $\mathrm{Sr}^{2+}$ ions from aqueous solutions using batch and fixed bed column operations. J. Hazard. Mater. 2008, 151, 432-445. [CrossRef]

50. Stapleton, M.G.; Sparks, D.L.; Dentel, S.K. Sorption of pentachlorophenol to HDTMA-clay as a function of ionic strength and pH. Environ. Sci. Technol. 1994, 28, 2330-2335. [CrossRef]

51. Kim, J.-H.; Shin, W.S.; Song, D.-I.; Choi, S.J. Sequential competitive sorption and desorption of chlorophenols in organoclay. Korean J. Chem. Eng. 2006, 23, 63-70. [CrossRef]

52. Dong, Y.; Wu, D.; Chen, X.; Lin, Y. Adsorption of bisphenol A from water by surfactant-modified zeolite. J. Colloid Interf. Sci. 2010, 348, 585-590. [CrossRef] 
53. Xie, J.; Meng, W.; Wu, D.; Zhang, Z.; Kong, H. Removal of organic pollutants by surfactant modified zeolite: Comparison between ionizable phenolic compounds and non-ionizable organic compounds. J. Hazard. Mater. 2012, 231-232, 57-63. [CrossRef]

54. Krajišnik, D.; Kaković, A.; Milojević, M.; Malenović, A.; Kragović, M.; Bogdanović, D.B.; Dondur, V.; Milić, J. Properties of diclofenac sodium sorption onto natural zeolite modified cetylpyridinium chloride. Colloids Surf. B 2011, 83, 165-175. [CrossRef] [PubMed]

55. Yang, K.; Zhu, L.; Xing, B. Adsorption of polycylic aromatic hydrocarbons by carbon nanomaterials. Environ. Sci. Technol. 2006, 40, 1855-1861. [CrossRef] [PubMed]

56. Li, L.; Liu, F.; Jing, X.; Ling, P.; Li, A. Displacement mechanism of binary competitive adsorption for aqueous divalent metal ions onto a novel IDA-chelating resin: Isotherm and kinetic modeling. Water Res. 2011, 45, 1177-1188. [CrossRef] [PubMed]

(C) 2020 by the authors. Licensee MDPI, Basel, Switzerland. This article is an open access article distributed under the terms and conditions of the Creative Commons Attribution (CC BY) license (http://creativecommons.org/licenses/by/4.0/). 